\title{
Molecular typing and mapping of MHC class II-DRB3 gene in Indian river buffaloes (Bubalus bubalis)
}

\author{
S. Sumathi, S.M.K. Karthickeyan, S.N. Sivaselvam and P.S. Rahumathulla \\ Dept. of Animal Genetics and Breeding, Madras Veterinary College, \\ Tamil Nadu Veterinary \& Animal Sciences University, Chennai - 600007 , India \\ kannikarthi@yahoo.co.in
}

\begin{abstract}
The present study was undertaken with the objectives of characterizing Bubu-MHC loci by PCR and genotyping MHC loci for allelic variation. The PCR product of second exon of the Bubu-MHC-DRB3 gene (304 bp) exhibited genetic polymorphism while digesting with Hael//enzyme resulting in three restriction fragment patterns in Murrah, four in Surti and three in Murrah graded buffaloes. In all the three genetic groups, the pattern ' $b$ ' (82, $222 \mathrm{bp}$ ) was frequently observed. The restriction fragment analysis with Rsal revealed five patterns in Murrah and three in Surti. The pattern 's' (67, 93, 144 bp) with a frequency of 0.4444 and 'l' $(67,237 \mathrm{bp})$ with a frequency of 0.5000 were observed. Microsatellite typing revealed nine alleles ranging from 160 to $212 \mathrm{bp}$ at the second intron. In Murrah, the allele $190 \mathrm{bp}$ was observed exclusively. In Surti, alleles 192 and 212 bp were observed more frequently. Rsal enzyme revealed more polymorphic patterns of DRB3 than Haelll. Microsatellite typing provided certain breed-specific alleles. This gene was physically localized to chromosome $2 p$ following tyramide signal amplification in between bands 15-22 using (cDNA probes derived from Bos taurus cattle) fluorescence in situ hybridization.
\end{abstract}

Keywords: Bubu-MHC; PCR-RFLP; FISH; buffaloes.

\section{Introduction}

The buffalo lymphocyte antigen system termed Bubu$\mathrm{MHC}$ is the major histocompatibility complex (MHC) of buffalo encoding disease resistance. The genes located in the class II region are highly polymorphic, the polymorphism being mainly located in the exon-2 which is characterized by large number of alleles at each locus and large number of amino acid substitutions between alleles. Selection for disease resistance will require investigation of genetic polymorphism of the MHC loci particularly DRB3 locus and identification of the genetic markers linked to disease resistance. Out of three DRB genes that have been identified so far, DRBP1 is a pseudogene and functional expression of DRB2 has not been found, while the DRB3 gene is functionally expressed. As many as 63 alleles had been identified at DRB3 exon 2 locus in cattle (Van Haeringen et al., 1999). The Bubu-MHC class II genes appear to be organised in a similar fashion to those of cattle and localized to chromosome two in buffaloes (lannuzzi et al., 1993).

Out of several molecular typing techniques, the Restriction Fragment Length Polymorphism (RFLP) analysis of gene segments amplified by the polymerase chain reaction (Van Eijk et al., 1992) and microsatellite based typing (Ellegren et al., 1993) have been found useful for DRB3 typing in cattle. Microsatellite based markers overcome many of the difficulties associated with the other marker types and have higher heterozygotes than RFLPs. Hence, it will be useful to develop a marker system for disease resistance by identifying a superior haplotype. Therefore, the present work on MHC genes in buffaloes was undertaken to characterise Bubu-MHC loci by polymerase chain reaction and to genotype Bubu-MHC loci for allelic variation. In addition, the class II-MHC probe has been used for mapping the major histocompatibility complex in Indian river buffaloes.

\section{Materials and methods}

A total of 36 animals comprising of 18 Murrah, 12 Surti and 6 Murrah graded buffaloes were utilized for this study. Ten $\mathrm{ml}$ of venous blood was collected under sterile conditions from each animal using EDTA ( $1 \mathrm{mg} / \mathrm{ml}$ of blood) as an anticoagulant. The genomic DNA was isolated by high-salt method as described by Montgomery and Sise (1990). The concentration and purity of DNA samples were estimated by UV spectrophotometer.

\section{PCR-RFLP typing of Bubu-MHC-DRB3 gene}

For amplifying the target sequence at Bubu-MHC DRB3 locus, primers such as LA31 and LA32 (Table 1) were used. The amplification reactions were carried out in a thermal cycler (MJ Research, USA) with an annealing temperature of $62^{\circ} \mathrm{C}$. Each $50 \mu \mathrm{l}$ reaction mix comprised of $100 \mathrm{ng}$ of template DNA, $100 \mathrm{ng}$ of each primer, $100 \mu \mathrm{M}$ of each dNTPs, 1.5 units of Taq DNA polymerase, $1.5 \mathrm{mM}$ of $\mathrm{MgCl}_{2}$ and 1X PCR buffer. Five $\mu \mathrm{l}$ of amplified PCR products were subjected to electrophoresis at 100 volts in $2 \%$ agarose gel in 1X TAE buffer containing $0.5 \mu \mathrm{g} / \mathrm{ml}$ of ethidium bromide along with DNA molecular weight marker and visualized by UV transillumination. The samples which showed amplification were stored at $-20^{\circ} \mathrm{C}$ prior to restriction studies.

Fifteen $\mu \mathrm{l}$ of amplified PCR products were digested separately with 10 units of restriction enzymes, viz. Haelll and $R s a l$ in a final volume of $20 \mu \mathrm{l}$ at $37^{\circ} \mathrm{C}$ for $90 \mathrm{~min}$. After completion of digestion, the enzyme was inactivated by 
adding $2 \mu \mathrm{l}$ of $0.5 \mathrm{M}$ EDTA ( $\mathrm{pH}$ 8.0). The RE digested fragments were separated on two per cent agarose gel in 1X TAE buffer ( $\mathrm{pH} \mathrm{8.3)} \mathrm{with} \mathrm{ethidium} \mathrm{bromide} 0.5 \mu \mathrm{g} / \mathrm{ml}$ and visualized under UV transilluminator. The pBR322/HaellI digest was used as DNA size marker. second exon of DRB3 gene which concurred with the report of Aravindakshan et al. (2000). Though the primers used were specific for cattle, the size of the amplified product in buffaloes was the same as that of cattle suggesting a strong conservation of DNA sequences between these two species.

Table 1. Microsatellite analysis of Bubu-MHC -DRB3 locus: Details of the primers used and the amplified products studied

\begin{tabular}{|c|c|c|c|c|c|}
\hline Locus & $\begin{array}{c}\text { Primer } \\
\text { Code }\end{array}$ & Primer sequence & $\begin{array}{l}\text { Primer } \\
\text { length }\end{array}$ & $\begin{array}{l}\text { Amplified } \\
\text { Product (bp) }\end{array}$ & Reference \\
\hline $\begin{array}{c}\text { Allele-specific } \\
\text { Bubu-MHC-DRB3 Locus }\end{array}$ & $\begin{array}{l}\text { LA31 } \\
\text { LA32 }\end{array}$ & $\begin{array}{l}\text { 5'-GATGGATCCTCTCTCTGCAGCACATTTCCT-3' } \\
\text { 5'-CTTGAATTCGCGCTCACCTCGCCGCTG-3' }\end{array}$ & $\begin{array}{l}30 \\
27\end{array}$ & 304 & $\begin{array}{l}\text { Sigurdardottir } \\
\text { et al. (1991) }\end{array}$ \\
\hline $\begin{array}{l}\text { Bubu-MHC-DRB3 } \\
\text { microsatellite }\end{array}$ & $\begin{array}{l}\text { LA53 } \\
\text { LA54 }\end{array}$ & $\begin{array}{l}\text { 5'-CGCGAATTCCCAGAGTGAGTGAAGTATCT-3' } \\
\text { 5'-GAGAGTTTCACTGTGCAG-3' }\end{array}$ & $\begin{array}{l}29 \\
18\end{array}$ & $160-212$ & $\begin{array}{l}\text { Ellegren } \\
\text { et al. (1993) }\end{array}$ \\
\hline
\end{tabular}

Two primers flanking the bovine DRB3 microsatellite, LA54 and LA53 (Ellegren et al., 1993) were used for the study. Each $20 \mu$ reaction mix comprised of $25 \mathrm{ng}$ of template DNA, 10 pmoles of each primer, $200 \mu \mathrm{M}$ of each dNTPs, 1.5 units of Taq DNA polymerase along with varying $\mathrm{MgCl}_{2}$ concentrations (1.5 mM \& $2.0 \mathrm{mM})$. The 10X PCR buffer with ammonium sulphate contained $670 \mathrm{mM}$ Tris-Hcl, 100 $\mathrm{mM}$ 2-Mercaptoethanol and $167 \mathrm{mM}\left(\mathrm{NH}_{4}\right)_{2} \mathrm{SO}_{4}, \mathrm{pH} 8.3$ at $25^{\circ} \mathrm{C}$. Thirty cycles with a primer annealing temperature of $50^{\circ} \mathrm{C}$ for $30 \mathrm{sec}$, as described by Ellegren et al. (1993) was adopted. Fifteen per cent polyacrylamide gels were used for analysis of microsatellite products. The gels were stained with ethidium bromide for $10 \mathrm{~min}$ and viewed under UV illumination. The alleles were scored, photographed and analysed by software aided gel documentation system.

\section{Fluorescent in situ hybridization (FISH)}

The metaphase and prometaphase chromosome spreads of the buffaloes were prepared using routine procedure. The class II-MHC probe, DRB3 clone 11-2, was procured from Roslin Institute, Scotland, UK which was a bovine $11 \mathrm{~Kb}$ PCR product of the complete DRB3 gene cloned into the vector PCR XL (Invitrogen). Biotin14-dATP labelled probe was hybridized as per the protocol mentioned by Chowdhary et al. (1995). Following high stringency post hybridization washes, signal amplification was carried out with biotinyl tyramide with the help of TSA ${ }^{\mathrm{TM}}$-Indirect (ISH) kit (NEN ${ }^{\mathrm{TM}}$ Life Science, NEL 730A). The chromosomes were counterstained with propidium iodide $(0.2 \mu \mathrm{g} / \mathrm{ml})$ and signals were screened and photographed in a Kodak 400 ASA film.

\section{Results and discussion}

On two per cent agarose gel, the amplified products showed a single band of $304 \mathrm{bp}$ fragment confirming

Table 2. Genotypes and allele frequencies of PCR-RFLP patterns of Bubu-MHC-DRB3 locus detected by Hae III restriction enzyme in buffaloes

\begin{tabular}{|c|c|c|c|c|c|c|c|c|c|c|c|c|}
\hline \multirow{2}{*}{ Breed } & \multicolumn{9}{|c|}{ Genotype frequencies } & \multicolumn{4}{c|}{ Allele frequencies } \\
\cline { 2 - 13 } & $\mathrm{a} / \mathrm{a}$ & $\mathrm{a} / \mathrm{b}$ & $\mathrm{a} / \mathrm{e}$ & $\mathrm{b} / \mathrm{b}$ & $\mathrm{b} / \mathrm{d}$ & $\mathrm{b} / \mathrm{e}$ & $\mathrm{d} / \mathrm{d}$ & $\mathrm{e} / \mathrm{e}$ & $\mathrm{a}$ & $\mathrm{b}$ & $\mathrm{d}$ & $\mathrm{e}$ \\
\hline Murrah & 0.1111 & 0.2777 & 0.0556 & 0.5000 & - & - & - & 0.0556 & 0.2777 & 0.6389 & - & 0.0834 \\
\hline Surti & - & 0.1667 & - & 0.3333 & 0.3333 & 0.0833 & - & 0.0834 & 0.0834 & 0.6248 & 0.1667 & 0.1251 \\
\hline $\begin{array}{l}\text { Murrah } \\
\text { graded }\end{array}$ & - & 0.1667 & - & 0.5000 & 0.1667 & - & 0.1666 & - & 0.0834 & 0.6667 & 0.2500 & - \\
\hline
\end{tabular}

Research article

CIndian Society for Education and Environment (iSee)

"Molecular typing of Indian buffaloes" http://www.indjst.org

\section{PCR-RFLP of DRB3 gene detected by Haelll}

The restriction fragment patterns of DRB3 gene observed in 18 Murrah, 12 Surti and six Murrah graded buffaloes are presented in Table 2. When the 304 bp PCR product of the DRB3 gene was digested with Haell/ enzyme, the patterns 'a' (170, 82 and 52 bp), 'b' (222 and 82 bp), 'd' (193, 82 and 29 bp) and 'e' (170 and 134 bp) were detected. No fragment corresponding to pattern ' $i$ ' (304 bp) described previously in buffalo (Aravindakshan et al., 2000) was observed in this study. In Murrah buffaloes, three different patterns " $a, b$ and e" were obtained with a frequency of $0.2777,0.6389$ and 0.0834 respectively. These patterns were seen in five different combinations. In Surti buffaloes, four fragment patterns "a, b, $d$ and e" with respective frequencies of $0.0834,0.6248,0.1667$ and 0.1251 in five different combinations were observed. In Murrah graded buffaloes, three patterns "a, b and d" with frequencies of $0.0833,0.6667$ and 0.2500 respectively in four different combinations were seen. No fragments of ' $d$ ' in Murrah and 'e' patterns in Murrah graded buffaloes were noticed.

The Haell/ pattern 'b' was the most frequently observed fragment with a frequency of $0.6389,0.6248$ and 0.6667 in Murrah, Surti and Murrah graded buffaloes respectively. The higher frequency of the pattern ' $b$ ' observed in the Murrah buffaloes is in agreement with the results of Aravindakshan et al. (2000). In Surti breed also the fragment pattern ' $b$ ' was observed to be more frequent in the present study while 'a' pattern was reported to be more frequent by Aravindakshan et al. (2000). In Murrah graded animals, the pattern ' $d$ ' was observed with a frequency of 0.2500 which was not detected in Murrah buffaloes. However, the pattern 'd' was observed by Arvindakshan et al. (2000) in Murrah animals with a very low frequency of 0.02 . The pattern 'i' (304 bp) with a frequency of 0.10 observed by Aravindakshan et Indian J.Sci.Technol. 
al. (2000) was not detected in the present study. The difference in fragment patterns of the present study and of Aravindakshan et al. (2000) might be due to differences in sample size and nature of the population of buffaloes used. However, Ahmed and Othman (2006) reported six genetic variants associated with amino acid substitutions.

Table 3. Genotypes and allele frequencies of PCR-RFLP patterns of Bubu-MHC-DRB3 locus detected by Rsa I restriction enzyme in buffaloes

\begin{tabular}{|c|c|c|c|c|c|c|c|c|c|c|}
\hline Breed & \multicolumn{5}{|c|}{ Genotype frequencies } & \multicolumn{5}{c|}{ Allele frequencies } \\
\hline & $\mathrm{l} / \mathrm{g}$ & $\mathrm{l} / \mathrm{s}$ & $\mathrm{m} / \mathrm{m}$ & $\mathrm{o} / \mathrm{s}$ & $\mathrm{s} / \mathrm{s}$ & $\mathrm{g}$ & $\mathrm{I}$ & $\mathrm{m}$ & $\mathrm{o}$ & $\mathrm{s}$ \\
\hline Murrah & 0.1111 & 0.2222 & 0.2222 & 0.2222 & 0.2222 & 0.0556 & 0.1667 & 0.2222 & 0.1111 & 0.4444 \\
\hline Surti & 0.5000 & 0.5000 & - & - & - & 0.2500 & 0.5000 & - & - & 0.2500 \\
\hline
\end{tabular}

\section{PCR-RFLP of DRB3 gene detected by Rsal}

Digestion of the $304 \mathrm{bp}$ PCR amplified second exon of the Bubu-MHC-DRB3 locus with the Rsal enzyme resulted in five restriction fragment patterns, ' $g$ ' (144,121 \& 39 bp), 'l' (237 \& $67 \mathrm{bp})$, 'm' (121, $114 \& 69 \mathrm{bp})$, 'o' (304 bp) and 's' (114, 93 \& $67 \mathrm{bp})$, which are presented in Table 3 . The Rsal patterns 'a' (81,67,54,39,33 \& 30 bp), 'b' (114,67,54,39 \& 30 bp), 'c' (114,93,67 \& 30 bp), 'f ' (144,67,54 \& 39 bp), 'h' (114,69,67 \& 54 bp), 'i' (183,67 \& 54 bp), 'n' (183 \& 121 bp) and ' $\mathrm{t}$ ' (160 \& 144 bp) reported in buffaloes (Aravindakshan et al., 2000) were not detected in the buffaloes typed. In Murrah, five different RFLP patterns ' $g$ ' (0.0556), 'T' (0.1667), ' $m$ ' (0.2222), 'o' (0.1111) and 's' $(0.4444)$ were found in five different combinations. The results were comparable with the findings of Aravindakshan et al. (2000). The patterns ' $m$ ' and 'o' were observed in different frequencies when compared with the previous report. The

Table 4. Microsatellite allele frequencies of Bubu-MHC-DRB3 locus in buffaloes
\begin{tabular}{|c|c|c|c|c|c|c|c|c|c|c|}
\hline Breed / & No. of & \multicolumn{8}{c|}{ Allele size (in bp) and their frequencies } \\
\cline { 2 - 12 } population & alleles & 160 & 167 & 180 & 185 & 190 & 192 & 195 & 208 & 212 \\
\hline Murrah & 4 & 0.3611 & - & 0.0555 & 0.1111 & 0.4723 & - & - & - & - \\
\hline Surti & 6 & - & 0.1667 & 0.0833 & - & - & 0.2500 & 0.0833 & 0.1667 & 0.2500 \\
\hline $\begin{array}{c}\text { Murrah } \\
\text { graded }\end{array}$ & 3 & 0.4167 & - & 0.0833 & 0.5000 & - & - & - & - & - \\
\hline
\end{tabular}
patterns "a, c, i, $\mathrm{n}$ and t" were not detected in Murrah breed in the present study, whereas these alleles were identified by Aravindakshan et al. (2000). In Surti, only three patterns,

Since there is no report available on microsatellite typing of Bubu-MHC-DRB3 gene in buffaloes, the results could not be compared. However, similar results were reported in Swedish Red and White, American Holstein-Friesian and 'g' (0.2500), 'I' (0.5000) and 's' $(0.2500)$ in two different combination were obtained. The patterns "a,b,f,h,i,m,n,o and t" reported earlier were not detected in Surti buffaloes. The frequencies of pattern " $\mathrm{g}, \mathrm{I}$ and $\mathrm{s}$ " were higher than those reported by Aravindakshan et al. (2000). In the present study, the Rsal enzyme revealed more polymorphic patterns (five) of the DRB3 locus than Haelll enzyme which produced only three patterns in Murrah. From the Fig. 1. Fish image of DRB3 gene on the metaphase chromosomes of Indian water buffaloes as twin dots on chromosome 2 of buffaloes hybridized with DRB3 probe (a and b) DRB3 signals and (c) Standard G - banded chromosome 2 of buffalo indicating localization of the gene.

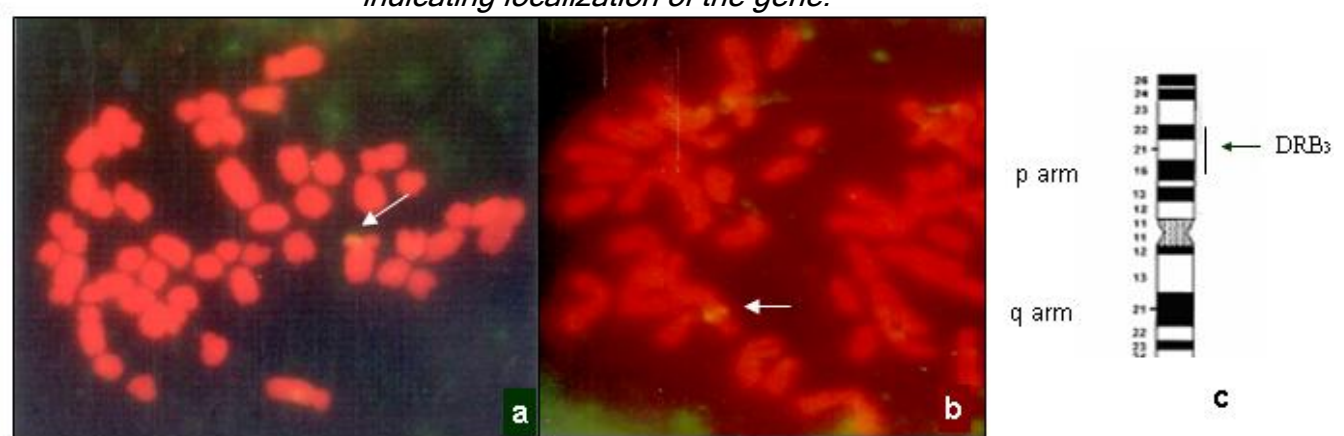
results of polymorphism observed in the present study and earlier reports (Sigurdardottir et al. (1991) and Van Eijk et al. (1992) in cattle and Aravindakshan et al. (2000) in

American Angus cattle by Ellegren et al. (1993). They observed 14 alleles ranging from 159 to $219 \mathrm{bp}$. Similar work was carried out by Van Haeringen et al. (1999) in
Research article

CIndian Society for Education and Environment (iSee)
"Molecular typing of Indian buffaloes" http://www.indjst.org
Sumathi et al. Indian J.Sci.Technol. 
Swedish Red and White breed of cattle who detected allele sizes ranging from 143 to $215 \mathrm{bp}$.

\section{FISH mapping of Bubu-MHC-DRB3 gene}

Strong and intense fluorescent hybridization signals were localized to river buffalo chromosome arm $2 p$ for class II regions (Fig. 1). Based on the standard karyotype (lannuzzi, 1994), the class II region was assigned to bands $2 p 15-22$. This is because of the wider and larger signals achieved due to tyramide amplification. The first chromosomal gene assignment in buffaloes was the major histocompatibility complex (MHC) by lannuzzi et al. (1993); they used class I MHC sequence probes and assigned the entire MHC gene complex to the p-arm of chromosome 2. In the present study, class II MHC probe was used specifically to demonstrate a close linkage between class I and II regions of MHC in buffaloes.

The following conclusions may be drawn from the present study: (1) PCR-RFLP is a powerful and sensitive technique for Bubu-MHC-DRB3 typing which is based on the extensive polymorphism detected with restriction enzymes, hence identification of superior haplotypes for disease resistance is possible, (2) The Rsal enzyme revealed more polymorphic patterns of DRB3 than Haelll enzyme and (3) Microsatellite typing of Bubu-MHC-DRB3 loci provide certain alleles which are specific to a particular breed and hence the use of markers for disease resistance.

\section{Acknowledgement}

The authors wish to express their gratitude to Dr. Rajiva Raman and Dr. Amit Kumar Rai, Cytogenetics Laboratory, Department of Zoology, Banaras Hindu University, Varanasi, UP for the assistance rendered to carry out the FISH work in their laboratory.

\section{References}

1. Ahmed S and Othman EO (2006) The characterisation of Haell/patterns in second exon of buffalo MHC class II DRB gene. Biotechnol. 5, 514-516.

2. Aravindakshan TV, Mahalinga Nainar $A$ and Sivaselvam S.N. (2000) Polymorphism in exon 2 of the Bubu-MHCDRB3 gene in Indian buffalo (Bubalus bubalis var. indicus) detected by PCR-RFLP. Anim. Sci. 70, 221226.

3. Chowdhary P, De la sene C, Harbit I, Eriksson I and Gustavsson I (1995) FISH on metaphase and interphase chromosomes demonstrates the physical order of the genes for GPI, CRC and LIPE in pigs. Cytogenet. Cell Genet. 71, 175-178.

4. Ellegren H, Davies CJ and Andersson I (1993) Strong association between polymorphisms in an intronic microsatellite and in the coding sequence of the BoLADRB3 typing gene: implications for microsatellite stability and PCR-based DRB3 typing. Anim. Genet. 24, 269-275.

5. Fries R, Hediger R and Stranzinger G (1986) Tentative chromosomal localization of the bovine major
Vol. 3 No. 5 (May 2010)

ISSN: 0974- 6846

histocompatibility complex by in situ hybridization. Anim. Genet. 17, 287-294.

6. Iannuzzi $L$ (1994) Standard karyotype of river buffalo (Bubalus bubalis L., 2n=50). Cytogenet. Cell Genet. 67, 102-113.

7. lannuzzi I, Gallagher DS, Womack JE, Di meo GP, Skow IC and Ferrara L (1993) Chromosomal localization of the major histocompatibility complex in cattle and river buffalo by in situ hybridization. Hereditas. 118, 187190.

8. Montgomery GW and Sise JA (1990) Extraction of DNA from sheep white blood cells. NZL. J. Agri. Res. 33, 437441.

9. Sigurdardottir S, Borsch C, Gustafsson K and Andersson I (1991) Cloning and sequence analysis of 14 DRB alleles of the bovine major histocompatibility complex by using the polymerase chain reaction. Anim. Genet. 22, 199-209.

10.Van Eijk MJT, Haynes JAS and Lewin HA (1992) Extensive polymorphism of the BoLA-DRB3 gene distinguished by PCR-RFLP. Anim. Genet. 23, 483-496.

12.Van Haeringen WA, Gwakisa PS, Mikko S, Erythorsdottir E, Holm LE, Olsaker I, Outteridge P and Andersson P (1999) Heterozygosity excess at the cattle DRB locus revealed by large scale genotyping of two closely linked microsatellites. Anim. Genet. 30, 169-176. 